\title{
TESHDJSAL IOTES
}

\section{Artemisia vulgaris L.: An Ornamental Plant for Disturbed Land Reclamation}

\section{GERALD E. SCHUMAN AND GENE S. HOWARD}

Highlight: Mugwort wormwood (Artemisia vulgaris L), an ornamental sage, shows promise in the reclamation of disturbed lands. Dryland plantings at several mine sites showed excellent survival and growth. Analysis of the plant material showed the average protein content was $31.5 \%$ and the average in vitro digestibility, $67 \%$. The low volatile oil content, $0.03 \%$, accounts for its palatability and digestibility as compared with other species of Artemisia.

Authors are soil scientist and horticulturist, respectively, U.S. Department of Agriculture, Science \& Education Administration - Federal Research, High Plains Grassland Research Station, Route 1, Box 698, Cheyenne, WY 82001.

This research was supported in part by funds from the Environmental Protection Agency. Interagency Agreement: EPA-IAG-D5-E763. Acknowledgment is given to Dr. Roy Teranishi for volatile oil analysis, U.S. Dep. Agr. SEA - Federal Res., Western Regional Research Center, Albany, Calif. 94710.

Manuscript received December 15, 1977

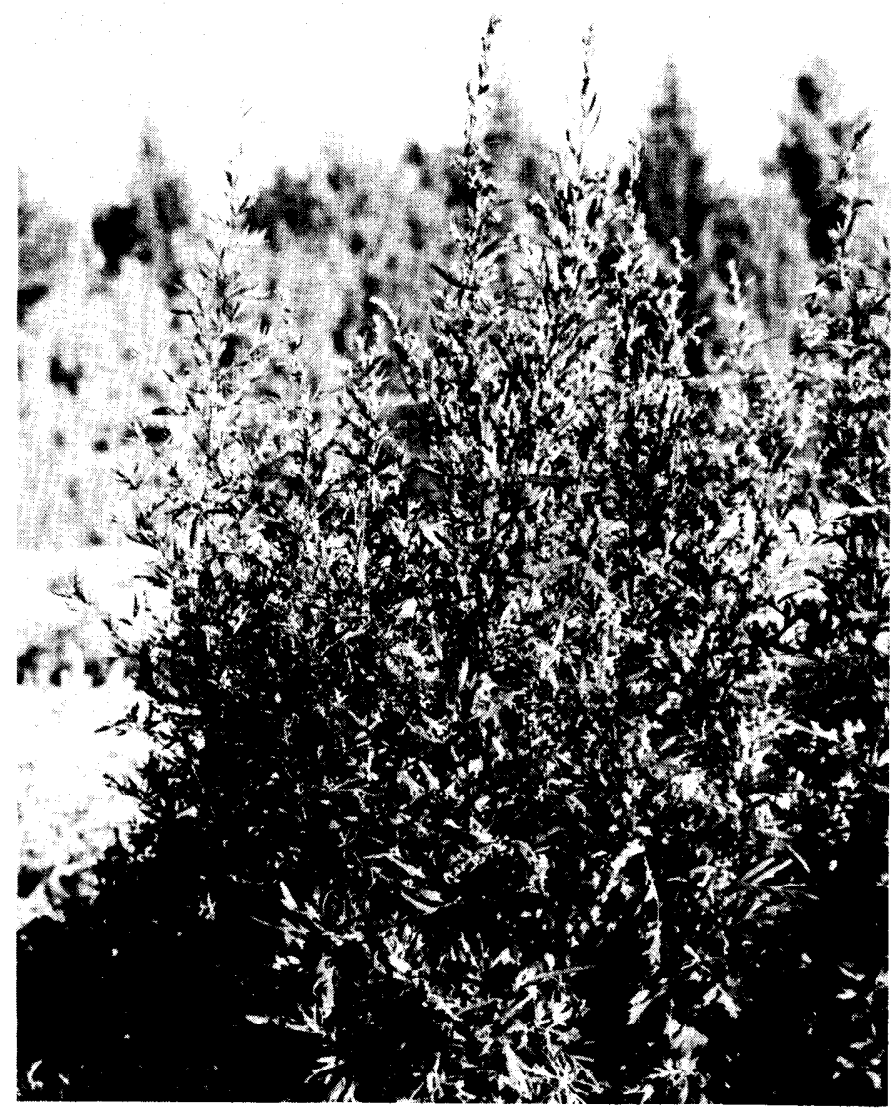

Fig. 1. Vien of mature Artemisia vulgaris plant and seed stalk.
Mugwort wormwood (Artemisia vulgaris L.), an ornamental sage, is native to Eurasia and was introduced to the eastern United States (Bailey 1930). It is adapted to a wide variety of soils and climatic conditions. Field plantings have been maintained at the High Plains Grassland Research Station, at Cheyenne, Wyo., since 1971. Several selections of this wormwood species have been made for flower and leaf variations to improve its ornamental value. At one time, this sage was used for medicinal purposes (Bailey 1930) and now shows promise in the reclamation of disturbed lands.

Mugwort wormwood is a herbaceous, vigorous, erect, multiple stemmed (to 20 or more) perennial that has branched flower panicles from the upper leaf nodes. Flowers are yellowish, small, numerous, and not showy. Leaves are alternate, gray tomentose beneath, green glabrous above, sometimes entire or pinnately cleft but most often palmately cleft (Fig. 1). Under irrigation, the

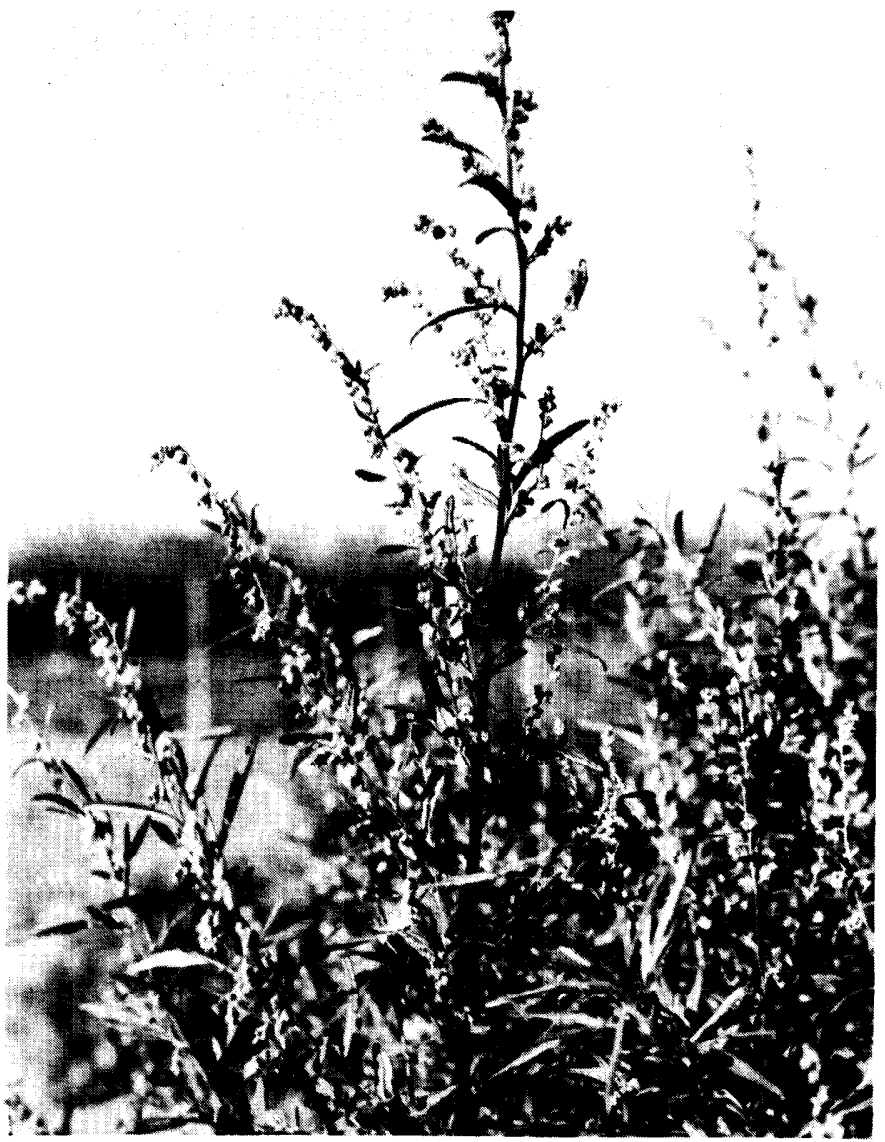


Table 1. Nutritional characteristics of Artemisia vulgaris at three growth stages.

\begin{tabular}{|c|c|c|c|c|c|c|c|c|c|c|c|c|c|}
\hline Growth Stage & $\begin{array}{c}\text { Protein } \\
\%\end{array}$ & $\begin{array}{l}\mathbf{P} \\
\%\end{array}$ & $\begin{array}{l}\mathrm{Ca} \\
\%\end{array}$ & $\begin{array}{c}\mathrm{Mg} \\
\%\end{array}$ & $\begin{array}{l}\mathbf{K} \\
\% \\
\end{array}$ & $\begin{array}{c}\mathrm{Na} \\
\%\end{array}$ & $\begin{array}{l}\text { Digesti- } \\
\text { bility } \%\end{array}$ & $\begin{array}{c}\text { Lignin } \\
\%\end{array}$ & $\begin{array}{c}\text { Cellulose } \\
\%\end{array}$ & $\begin{array}{c}\text { Ash } \\
\%\end{array}$ & $\mathrm{NDF}^{\prime}$ & $\mathrm{ADF}^{2}$ & $\begin{array}{c}\mathrm{DM} \\
\%\end{array}$ \\
\hline $\begin{array}{c}\text { Preflowering } \\
(7-22-76)\end{array}$ & 31 & .55 & 1.57 & .33 & 4.57 & .11 & 69 & 7.9 & 13.4 & 16.3 & 27.3 & 23.8 & - \\
\hline $\begin{array}{l}\text { Maturity } \\
\quad(8-30-76)\end{array}$ & 32 & .53 & 1.41 & .31 & 4.93 & .10 & 66 & 9.7 & 19.1 & 13.2 & 32.6 & 30.2 & 19 \\
\hline $\begin{array}{l}\text { Post-maturity } \\
(11-3-76)\end{array}$ & 12 & .28 & 2.25 & .27 & 2.1 & .07 & 64 & 8.2 & 22.2 & 11.7 & 34.1 & 32.7 & - \\
\hline
\end{tabular}

1 Neutral detergent fiber.

2 Acid detergent fiber

plant will grow to $2 \mathrm{~m}$ tall and on dryland to $1-11 / 2 \mathrm{~m}$. It does not have a strong aromatic fragrance like other sages. Seeds are small and dark brown with about $2,200 \mathrm{seed} / \mathrm{g}$.

This plant seems to have promise in reclamation of mined and other disturbed lands. Seed production under cultivation is not a serious problem nor would harvesting require special equipment.

\section{Methods}

Seedlings of mugwort wormwood were grown in a greenhouse in $7.5 \mathrm{~cm}$ clay pots and transplanted at five mine sites in Wyoming and one in Colorado in 1975 and 1976 into moist soil and not irrigated again. Average height of the transplants was $10 \mathrm{~cm}$. Direct seeding using a cone seeder was tested at two locations in the fall of 1976 and the spring of 1977 . The six sites represent a wide range of soil and climatic conditions. Elevation of the sites ranges from 1,371 to $2,438 \mathrm{~m}$ above sea level. Annual precipitation ranged from 25 to $76 \mathrm{~cm}$.

Plant material was harvested at several stages of growth from field plantings $(0.1 \mathrm{ha})$ at the High Plains Grassland Research Station, Cheyenne, Wyo. Random samples of the entire plant were obtained on July 22, August 30, and November 3, in 1976 for nutritive and mineral analysis. The November sample was taken to determine the plant's nutritional value as winter feed for wildlife and livestock. Digestibility was determined by the in vitro method described by Tilley and Terry (1963).

\section{Results and Discussion}

The dryland plantings of mugwort wormwood had excellent survival (greater than $90 \%$ ) and growth. The plants were so attractive to antelope, decr, and rabbits that cxclosurcs were needed to grow mature plants. When not protected by exclosures, grazing by wildlife was so heavy that plants seldom were able to grow more than 15 to $20 \mathrm{~cm}$ tall. However, even with the close grazing and the severe drought during this period, survival was greater than $90 \%$ over the 3 -year period. Protected plants were about $1 \mathrm{~m}$ tall by the third year.

No seedling emergence was evident from the 1977 spring direct seeding trials at either location, whereas the 1976 fall seeding resulted in an acceptable stand. More research is needed to determine the best time, depth, and method of seeding.
Analysis of whole plant material at various stages during the growing season showed the average protein content was $31.5 \%$ (Table 1). This is considerably higher than that of range shrubs and forbs (Hamilton and Gilbert 1972). The November samples had a protein content of $12 \%$. The phosphorus content during the growing season averaged $0.54 \%$, which is equal to or above the nutrient requirement for finishing cattle (National Academy of Sciences 1976). The calcium, magnesium, potassium, and sodium content resemble those of other range shrubs and forbs (Hamilton and Gilbert 1972). However, the quality of the plant material is higher than that of the native shrubs and forbs. The average in vitro digestibility of new plant growth is $67 \%$, which equals or exceeds that of many forage species grown for hay. This plant has a volatile oil content of only $0.03 \%$, which accounts for its palatability and digestibility as compared with other species of Artemisia. For example, the volatile oil content of Artemisia tridentata ranges from 1 to $1.26 \%$ (Kinney et al. 1941; Adams and Billinghurst 1927; Adams and Oakberry 1934).

Mugwort wormwood seems to have several characteristics that make it a useful plant for seeding with grasses and other shrubs on disturbed lands in the arid and semiarid areas. It is hardy, adaptable to a wide variety of soils and climatic conditions, and highly nutritious to both domestic livestock and wildlife.

\section{Literature Cited}

Adams, M., and R. Billinghurst. 1927. Essential oils in desert plants I. Physical Constants. J. Amer. Chem. Soc. 49:2895-2897.

Adams, M., and F. S. Oakberry. 1934. Essential oil in desert plants. III. Examination of the oil of Artemisia tridentata Typica. J. Amer Chem. Soc. 56:457-459.

Bailey, L. H. 1930. The Standard Cyclopedia of Horticulture. Volume 1. The Macmillan Company, New York, N.Y. 1200 p.

Hamilton, J. W., and C. S. Gilbert. 1972. Composition of Wyoming range plants and soils. Res. J. 55. Wyoming Agr. Exp. Sta., Laramie. 14 p.

Kinney, C. R., T. M. Jackson, L. E. DeMytt, and A. W. Harris. 1941. Oil of Artemisia tridentata (American Sage Brush). J. Organic Chem. 6:612-625.

National Academy of Sciences. 1976. Nutrient Requirements of Beef Cattle, National Academy of Sciences, Washington, D.C. 56 p.

Tilley, J. M. A., and R. A. Terry. 1963. A two-stage technique for the in vitro digestion of forage crops. J. Brit. Grassl. Soc. 18:104. 